Article

\title{
Environmental Policy Stringency, Technical Progress and Pollution Haven Hypothesis
}

\author{
Elkhan Richard Sadik-Zada ${ }^{1,2,3,4,5, *}$ and Mattia Ferrari ${ }^{3,6}$ \\ 1 Institute of Development Research and Development Policy, Ruhr-University, 44801 Bochum, Germany \\ 2 Centrum für Umwelt, Ressourcen, Energie (CURE), Faculty of Management and Economics, \\ Ruhr-University, 44801 Bochum, Germany \\ 3 Centre for Studies on European Economy (AIM), Azerbaijan State University of Economics (UNEC), \\ Baku 1001, Azerbaijan; mattia.ferrari@rub.de \\ 4 Center for Economic Development and Social Change (CED), 80128 Napoli, Italy \\ 5 Energy Transitions at Cambridge (Visiting), University of Cambridge, Cambridge CB2 1TN, UK \\ 6 European Institute for Innovation-Technology e.V., 73525 Schwäbisch Gmünd, Germany \\ * Correspondence: Elkhan.R.Sadik-Zada@ruhr-uni-bochum.de; Tel.: +49-(0)-234-32-25153
}

Received: 17 March 2020; Accepted: 1 May 2020; Published: 9 May 2020

\begin{abstract}
The present inquiry provides a common ground for the analysis of two strands of literature, the environmental Kuznets curve (EKC) and the pollution haven hypothesis (PHH). To this end, the study sets out a simple variational model, which identifies the structural composition of the economy and the level of economic development as the primary determinants of the magnitude of the domestic environmental degradation. The juxtaposition of the mentioned literature strands undermines the optimistic view that economic growth, in the long run, leads to the reduction of atmospheric pollution. To assess the empirical validity of the pollution haven conjecture, the study employs the OECD Environmental Policy Stringency Index and the refined data on carbon emissions embodied in imports for the dataset of 26 OECD countries in the time interval between 1995 and 2011. By employing pooled mean group (PMG) estimators, the study, for the first time, accounts for a number of issues mentioned in the literature as factors that confine the inferential power of existing empirical studies on the EKC. The strong and robust confirmation of the pollution haven conjecture indicates that at least in the context of global common pool resources, a purely national perspective of the EKC is not satisfactory.
\end{abstract}

Keywords: environmental policy stringency; carbon leakage; pollution havens; intensity-of-use hypothesis; development economics; environmental Kuznets curve; calculus of variations; pooled mean group estimator

\section{Introduction}

OECD countries are occupying the top positions with regards to climate change awareness. More than $90 \%$ of the population in the OECD countries are aware of climate change and more than $60 \%$ of them deem climate change a serious threat for the sustainable livelihood and international security [1]. An investigation of the European Investment Bank (EIB) shows that 91\% of Europeans consider climate change as an existential risk. $72 \%$ of the Europeans support the idea of the extension of carbon tax on consumption in order to reduce environmental degradation. A total of $44 \%$ of Europeans support stricter pollution controls on industry and especially on the energy sector [2,3]. Despite their relatively low Climate Change Performance Index, which condenses the climate protection performance of 57 countries, the OECD members Australia, Canada and the US belong to the countries with strong awareness of the risks related to climate change, and have relatively stringent environmental regulations 
in the global comparison. In 2012, Australia introduced an emission trading system (ETS). In 2018, Canada kicked off a nation-wide ETS. Nine northern US states and California price carbon, whereby only California has a carbon pricing system that covers a substantial share of emissions and has an appropriate carbon price (15 USD per metric ton $\mathrm{CO}_{2}$ ). The northern states massively underprice carbon emissions. Nevertheless, the overwhelming majority of Americans support the revenue-neutral carbon tax, i.e., if the collected taxes are used directly to protect and upgrade the natural environment [4].

The awareness on climate change risks and the importance of environmental regulations is steadily increasing in developing countries too [5]. In countries such as Ecuador, Bangladesh, Trinidad and Tobago, and Venezuela, for instance, the level of awareness of climate change risks, with $99 \%, 98 \%$, $97 \%$ and $98 \%$, respectively, is even higher than in some advanced countries [1]. Faure and Partain [5] point out that less developed countries have greater challenges in terms of financial leeway and institutional capacities for the formulation of efficient environmental policies and implementation of the corresponding regulations. The huge gap in the Environmental Performance Index (EPI) between advanced and developing countries shows that rising environmental awareness in the Global South is still not enough for bridging this gap [6].

In tendency, developing countries still have laxer environmental regulations, especially in terms of carbon emissions, which are manifested in the geography of the pricing or taxing emissions. Worldwide, there are only 40 countries that have already introduced or have concrete plans for taxing emissions that emanate from combusting fossil fuels like coal, oil and natural gas. Most of them are high-income countries. None of the low-income countries impose a carbon tax. Developing nations that consider a carbon tax, including China, Mexico, South Africa, Turkey, Indonesia, Kazakhstan and Brazil, are all emerging high to middle-income economies [7].

The differences in the content and stringency of environmental policies in combination with trade liberalization could trigger the relocation of pollution-intensive industries or the divisions of value chains from industrialized economies to the jurisdictions with lax or no environmental regulations. Even with carbon taxing in the respective developing countries, the tax burden in the developing areas, imposed on the same multinational enterprise for the same amount of emissions, is in the developing areas much than in the advanced and emerging economies [3]. This kind of internationalization of the value chains of the pollution-intensive industrial production, dubbed "pollution haven hypothesis" (PHH) or "carbon leakage", has been first proposed by Copeland and Taylor [8].

The central problem in the context of the global climate change is not only the relocation of the "dirty" industries to the countries with lax or no environmental regulations, but rather the net increase of emissions due to lax environmental regulations in the new locations. If so, then outsourcing of the production from the developed to the developing countries has a positive net carbon footprint. One example: the recycling of old batteries in the US is a stringently regulated area because of the health risks related to the lead contained in batteries. Mexico has no regulation of these processes and thus has morphed, at least with regards to the recycling of old batteries, into a pollution haven for the US [9].

In 2015, the contemporary "workshop of the global manufacturing", People's Republic of China initiated eight pioneer ETS projects in Beijing, Shanghai, Guangdong, Hunei, Tianjin, Chongging and Shenzgen. In 2020 China plans to introduce a countrywide ETS system. Could the planned implementation of a China-wide ETS trigger a new wave of relocation of dirty industries from China to other jurisdictions with surplus labor and substantial natural resources, such as Sub-Saharan Africa, Central Asia and South-East Asia? Or would the nation-wide ETS in China rather stimulate carbon-saving innovations? Thus, the upcoming implementation of ETSs in a number of developing and transitioning economies, the increasing environmental stringency in the OECD countries, especially Germany, and the EU's planned carbon border tax all contribute to the topicality of the analysis of the responsiveness of carbon-intensive manufacturing to the increasing tightness of environmental regulations.

The paper at hand reappraises the pollution haven hypothesis $(\mathrm{PHH})$ with a refined dataset for 26 OECD member countries and advanced cointegration methods, which have not been employed 
for the analysis of the PHH yet. To this end, the study analyzes the nexus between the stringency of environmental policies in the OECD member countries and carbon leakage. The study also accounts for the possibly of the mitigating power of the Porter effect. The Porter effect, also known as Porter hypothesis (PoH), has been suggested by Porter and van der Linde [10]. According to PoH, strict environmental regulation fosters alternative business models, for instance the implementation of resource-efficient production processes based on circular economy and the development of climate mitigating technological advances [11,12]. Under the burden of environmental regulation, the companies develop new production techniques that lead to first-mover advantages and learning by doing effects. Despite its prominence, the empirical validation of the $\mathrm{PoH}$ has been confined to the companies striving cost leadership, which have relatively small product portfolios [13].

Despite a large and rigorous corpus of theoretical literature on the $\mathrm{PHH}$, the empirical cross-country literature on the $\mathrm{PHH}$ and $\mathrm{PoH}$ is rather inconclusive [14-16]. In addition, there is a host of incongruences related to the employed indicators of environmental policy stringency and technological adjustment. Further, with the exception of Jobert et al. [16], there is no known empirical analysis of the PHH that accounts for the time series character of the analyzed data.

The paper contributes to the literature on the PHH in three ways. First, it suggests a tractable analytical model of environmental degradation in the framework of the calculus of variations. The model disentangles the forces determining the magnitude of environmental degradation. Second, the study employs for the first time the Environmental Policy Stringency Index (EPSI), the recycling rate and imported carbon emissions of the OECD for the test of the pollution haven conjecture. The mentioned variables are more precise and yield more reliable estimation results. Previous literature mostly employed rather fuzzy indicators of the $\mathrm{PHH}$, such as gross greenhouse gases (GHGs) or total $\mathrm{CO}_{2}$ emissions. The third contribution of this inquiry is related to the employed estimation methodology. This is the first study that accounts at the same time for issues such as panel heterogeneity and mixed stationarity in the assessment of the PHH by employing pooled mean group (PMG) estimators proposed by Pesaran et al. [17].

The paper proceeds as follows. Section 2 analyzes the relevant literature. In Section 3 we descriptively illustrate two scenarios, whereby the national reduction of the GHGs is driven by the relocation of the carbon-intensive manufacturing overseas. Section 4 sets out a variational analytical model that identifies, on the theoretical level, the sectoral composition of the economy and the level of economic development as the primary factors that determine the level of pollution in the individual economies. Section 5 is dedicated to the underlying estimation methodology. Section 6 delves into data issues. In Section 7, we present the estimation results, and Section 8 concludes.

\section{Structural Change and Environmental Degradation}

The discussion on economic activities and pollution dynamics dates back to the early 1970s as the economists of the "Club of Rome" in the Limits to Growth reawakened the old views of the classics, David Ricardo and Thomas Malthus, that in the face of the finiteness of the natural resources and environmental endowments, growth of the economies cannot be sustained in the long term [18]. They urged instead for zero-growth steady state economies [19]. This lead to the surge of the theoretical elaborations on optimal growth, abatement policies and trade openness [20-22]. These studies were in line with the recommendations of the "Club of Rome". Nevertheless, there were also critical voices. The most influential of them was Malenbaum [23,24], who strengthened the World Steel Association's Intensity-of-Use (IoU) hypothesis. The IoU hypothesis has been predicated on the analysis of the relationship between metal-intensity and per capita income [25]. He detected an inverted U-shaped relationship between metal-intensity and the average income.

Although Malenbaum [24] points to the improvement of the efficiency of intermediate inputs and structural change, expressed in the tertiarization of the economy, as the cause of the declining material intensity of the GDP, he considers the structural component of the mentioned phenomenon as the primary driver of the declining material intensity. Although Malenbaum [23,24] addressed 
the increasing efficiency of intermediate input use, he ignored the role of innovation in finding the substitutes. Substitutes like plastics contributed substantially to the reduction of the metal-intensity of modern manufacturing [26]. Hence, the underlying idea behind the IoU hypothesis is deeply rooted in the structuralist paradigm of economic modernization [27-34]. De Bruyn [35] defines structural transformation in the ecological context as "quantitative and qualitative changes in the composition of economic activities that result in different environmental pressures".

At the pre-capitalist stage of economic development, the economy is based on subsistence, i.e., not mechanized agriculture, primitive handicraft, petty trading and domestic service [36]. At this stage, only labor force is the essential production factor. Capital at this stage consists only of the primitive means of production and has a negligible contribution to the value creation, i.e., gross domestic product [37]. The material and energy requirements in the pre-capitalist milieu are low. The initial capital accumulation and burgeoning capitalism hallmark a take-off in terms of economic growth.

The take-off leads to the growth of the material-and energy-intensive activities, such as construction, mining and manufacturing. After the demand for the manufactured goods, houses, factories, transport infrastructure and power generation stations has been satiated, the demand for services starts to increase [25]. This is in line with the predictions of Engel [38] and Pasinetti [39,40]. The tertiary sector is less material- and energy-intensive than manufacturing, mining and construction. Advancing tertiarization leads to the decreasing material and energy use per unit of GDP [41]. Hence, the material and energy intensity of the economy starts to decline.

The seminal contribution of Grossmann and Krueger [42,43] led to the re-awakening and proliferation of Malenbaum's ideas [24]. Their work has been inspired by the foundation of the North American Free Trade Agreement (NAFTA) and its related environmental risks for Mexico. The authors re-detected an inverted U-shaped relationship between the level of the average income and environmental degradation. This gave an impetus for the burgeoning of studies delving into the role of environmental regulations and trade liberalization as the concomitants of the growing level of the average income. Because of its analogy to the Kuznets curve hypothesis suggested by Kuznets Simon [44], Panayoutou [45] dubbed this relationship the environmental Kuznets curve (EKC).

The idea behind EKC is in line with the explanation of the IoU hypothesis, which foregrounds the change of the sectoral structure as the primary explanation of the EKC. In the following, the intensity of the environmental degradation is delineated graphically in Figure 1. The phases of economic development have been separated by the dashed vertical lines. In the pre-capitalist economy, there is an intact environment because of the relatively low intensity of the anthropogenic impact on natural amenities. The economy evolves at a low level of subsistence income. After capitalistic "take off" and the emergence of the manufacturing, mining and market-oriented agriculture, the economy starts to grow at a greater pace. Hence, the slope of the environmental degradation curve becomes steeper in the industrialization phase. Manufacturing is the leading sector that fuels growth in all the sectors by growing itself [46-48].

Economic growth in the industrializing societies correspond with the increasing environmental degradation. A higher level of income and the resulting tertiarization lead to a greater environmental awareness, and pushes cleaner production techniques [49,50]. Services, in contrast to mining and manufacturing, have a much smaller emission factor [51]. This leads to the leveling off and gradual decline of environmental degradation [49]. As depicted in Figure 1, at the last stage the level of degradation starts to decrease. Besides of tertiarization, the rise of the knowledge economy also contributes to a greater material-efficiency of the economy.

A group of influential environmental and resource economists, such as Kenneth Arrow, Bert Bolin, Robert Constanza, Partha Dasgupta, Carl Folke, C.S. Holling, Bengt-Owe Jansson, Simon Levin, Karl-Göran Möler, Chares Perrigs and David Pimentel intervened decisively in the debate on the EKC hypothesis with their joint paper in Arrow et al. [52] in Science, and expressed their skepticism concerning the growth optimism in the context of the EKC hypothesis. The authors agreed with the underlying logic behind the cleaning effect of economic growth: 
"One explanation of this finding is that poor countries cannot afford to emphasize amenities over material well-being. Consequently, in the earlier stages of economic development, increased pollution is regarded as acceptable side effect of economic growth. However, when a country has attained a sufficiently high standard of living, people give greater attention to environmental amenities. This leads to environmental legislation, new institutions for the protection of environment, and so forth." ([52], p. 106).

Notwithstanding basic agreement with the EKC hypothesis, the authors also mention a number of reasons for caution in interpreting the nonlinear income-environment nexus. The central cause for the skepticism, especially concerning global atmospheric pollution with stock pollutants such as carbon dioxide, is related to the global implications of the emissions. If reduction in the pollutant in one country leads to the transfers of pollutants to other countries, then the net GHG footprint is not necessarily negative. This was the reflection of the awareness about the role of international trade as the catalyst of the pollution haven formation in jurisdictions with lax or no environmental regulations [8].

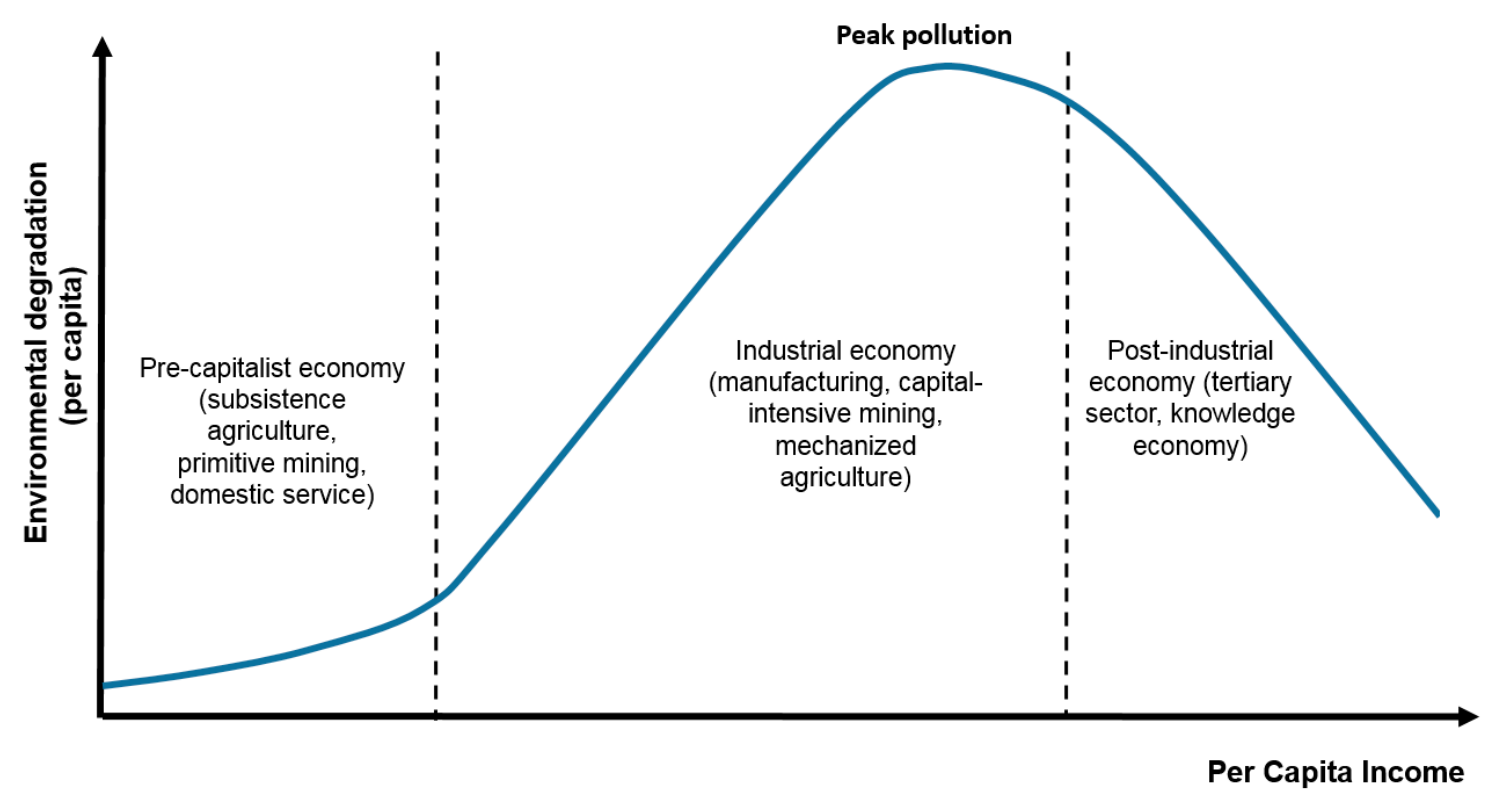

Figure 1. Structuralist approach to the environmental Kuznets curve (EKC).

According to Malenbaum [24], developing countries at the industrialization stage have, similarly to the advanced economies, rapidly increasing emission dynamics. Nevertheless, assuming that South Korea in the early stages of its industrialization in the 1970s repeated the emission intensity of Great Britain in the 1860s is not correct. Due to a substantial progress in knowledge and available technologies, the South Korean steel industry in the 1970s was much cleaner than that of advanced capitalist countries at the end of the nineteenth century. Further, Malenbaum [24] refers also to the contemporary differences in the state of the technology between advanced and developing nations at many instances. Richard Auty [26], in his reference, writes that Malenbaum [24] states that although material usage intensity patterns of the developing countries will be lower than those of rich countries at comparable levels of per capita GDP, they will be unable to fully adopt the best of modern technologies that are mostly available in the technologically advanced economies with stringent environmental policies.

Besides the stringency of environmental regulations and the technology gap, there is also a third essential barrier for the deployment of advanced carbon-saving technologies from the Global North to the Global South. This is the underdevelopment of the intellectual property rights (IPRS) regime, which is regulated by the World Trade Organization Agreement on Trade related Aspects of the IPRs (TRIPS) [53]. Enforcement of IPRs protection does not generate higher transfer of environmental technologies due to the poor governance, the small size of the economies and the low level of the 
corresponding scale effects [54,55]. Maskus and Reichman [56] indicate the need for a balanced approach to the issue of the attraction of the foreign direct investments(FDI) and carbon-mitigating technology transfers in the context of the Global South. Littleton [53], by contrast, takes the view that in the face of a greater responsibility of the developed countries, this balance has to be tilted towards technology transfer from the Global North to the Global South. In our opinion, the financial and institutional assistance for the transfers of the carbon-saving technologies has to be implemented in the framework of international development cooperation. A larger deployment of climate-friendly technologies in the least developed countries could substantially reduce the negative environmental externalities on the global scale stemming from the relocation of polluting industries.

\section{Juxtaposing the Environmental Kuznets Curve and Pollution Haven Hypotheses}

In this subsection, by juxtaposing the EKC hypothesis with the PHH, we show graphically that an inverted U-shaped income-environment relationship could be the result of the relocation of carbon-intensive production divisions overseas, i.e., the establishment of pollution havens. Broadening of the perspective from the national EKC to the international or global pollution framework is necessary in the context of the global climate change, whereby atmosphere serves as a global common good as sink for global GHGs.

We illustrate two scenarios whereby the international mobility of the manufacturing value chains imply that in the context of global environment, the observed national EKCs are just artifacts. Furthermore, the national EKCs can incur not only an emission-neutral but also an emission-augmenting effect. The scenarios are illustrated in Figure 2.
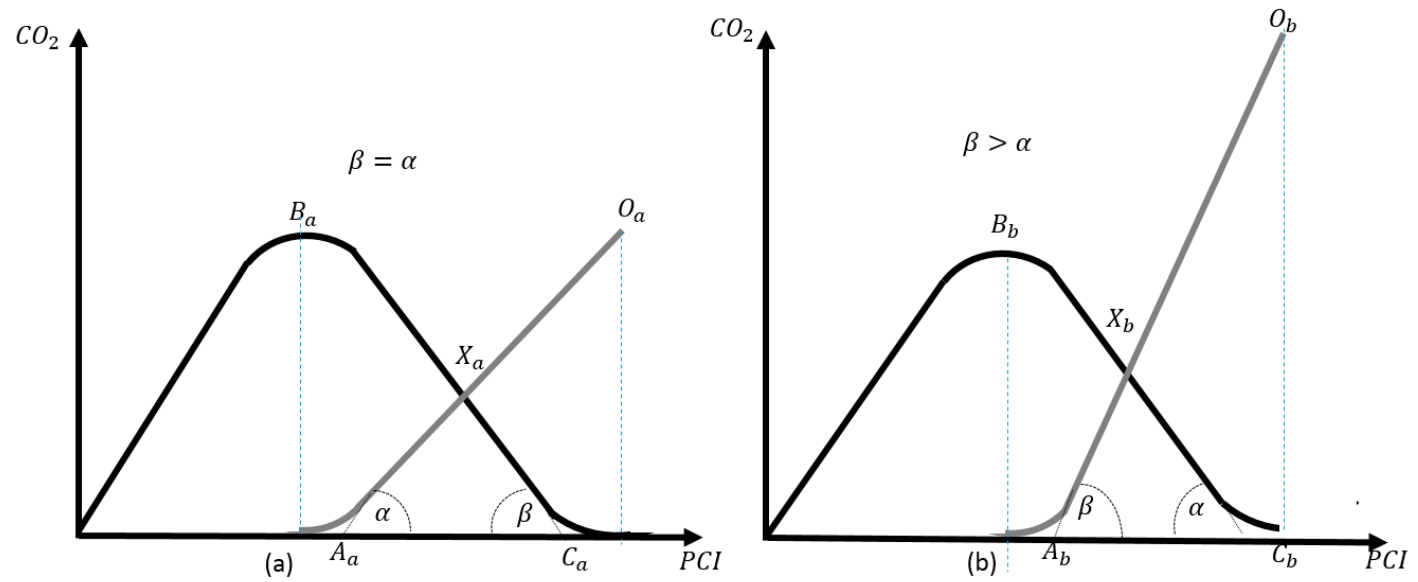

Figure 2. Carbon leakage with (a) zero and (b) negative net greenhouse gas (GHG) footprint.

The first scenario is a zero-sum relocation, whereby the migration of the dirty industries to the less-developed countries has a zero net effect on carbon emissions. The emissions in one country are now emitted in another country using the same production and abatement technologies (Figure 2a). Under these conditions, the inverted U-shaped income-environment relationship comes to its own via carbon leakage. Hence, this kind of carbon leakage leads to the realization of the spurious environmental upgrading effect and has no effect on the gross carbon intensity for the production of the same amount of goods. Figure $2 b$ depicts a situation whereby the industries are relocating to the jurisdictions, where the output of the same quantity of output requires more carbon emissions than production at home.

Because of the identity of the emission factors under scenario (a), the angles $\alpha$ and $\beta$ of the triangle $A_{a} X_{a} C_{a}$ are equal. This implies that the carbon leakage equals the reduction of carbon emissions at home. Under scenario (b), the angle $\beta$ of the triangle $A_{b} X_{b} C_{b}$ is greater than the angle $\alpha$, i.e., one unit reduction of emissions at home leads to a more than one unit increase of emissions abroad. Hence, this is a scenario with a net positive carbon footprint. The scenario (b) holds if the jurisdictions have 
different technologies or environmental regulations concerning environmental pollution. The triangle $A_{a} \mathrm{O}_{a} C_{a}$ indicates pollution overseas that can be attributed to relocation or outsourcing of the domestic industry in the case of homogenous emission factors. In the case whereby the foreign jurisdiction has a greater emission factor, i.e., scenario (b), the emissions that could be attributed to relocation of outsourcing of the domestic industries are commensurate with the triangle $A_{b} O_{b} C_{b}$. The negative net footprint of this kind of internationalization of production equals the difference between the areas of $A_{a} \mathrm{O}_{a} \mathrm{C}_{a}$ and $A_{b} \mathrm{O}_{b} \mathrm{C}_{b}$.

Nevertheless, the assumption of the general technology gap between the heavy industries of developing and developed countries is not straightforward, especially if the countries of interest are not practicing import substitution policies. This holds even more for World Trade Organization (WTO) member states. Most pollution-intensive industries are heavy industries, such as metallurgy, the petroleum industry and cement production. To survive in the global competition, these industries are competing with each other for technological leadership that leads to cost advantage. Labor-technology substitution possibilities are rather limited in these capital-intensive industries. Especially the metallurgy and petroleum industries of the Global South are the "islands of modernity" in the terms of Sir Arthur Lewis [36]. They are comparable to the analogous sectors in the Global North. The only systematic difference with regards to technology that could favor the competitiveness of the developing countries is related to the lax regulations and taxation of polluting activities in the less-developed countries.

\section{A Model of Environmental Degradation}

We suppose that at $t_{0}$ there is a fixed amount, $E_{0}$, which is the stock of the natural environment. In the context of the proposed model, we could think of the natural environment as a measure of total natural environment or a specific aspect of it, e.g., the available soil, water or air resources. Johnson et al. [57] confine the natural environment to the part of the total environment that has not been affected by human culture, that is, without anthropogenic intervention. $E(t)$ is the measure of environmental degradation in period $t$, whereby environmental degradation in contrast to natural or environmental change is a disturbance that sources from the human intervention into the natural environment ([57], p. 584).

In the framework of this investigation we focus on carbon dioxide emissions. Hence, environmental degradation in the framework of this model is related to the extraction of fuel and nonfuel mineral endowments, their refinement and combustion. It is assumed that the exploitation of fossil riches contributes to the gross economic value added of the country. This utility has a monetary value. For the sake of simplicity, we normalize the contribution of one unit of the environmental quality to the value added to $q(t)$. $T$ is the time juncture at which the use of the environmental assets stops due to the depletion or increasing costs related to the degradation of environmental quality or arriving at the critical mass (disutility) concerning air, soil or water quality [58]. Hence,

$$
\int_{0}^{T} E(t) d t \leq E_{0}
$$

To simplify the presentation, we assume without any loss of generality that there are no extraction costs. The society carries costs, i.e., externalities that are related to the depletion of the natural environments, $C(E(t), t)$. These are the externalities of the manufacturing sector. These costs depend on the magnitude of the resource revenue in period $t, E(t)$. Thus, we denote the costs incurred due to depletion of environmental goods as $C(E(t), t)$.

The economic value added (EVA) is related to environmental degradation, commensurate with the following expression:

$$
\text { Economic Value Added }=q(t) E(t)+M(E(t), t)-C(E(t), t)
$$


$M(E(t), t)$ is part of the manufacturing output minus costs, i.e., manufacturing value added (MVA), which is attributed to the exploitation of the natural environment. $M(E(t), t)$ is not the total manufacturing sector output. It is its part that can be attributed to the existence of the extractives' sector.

If $r$ is the relevant discount rate then the total discounted EVA in the relevant time horizon, $[0 ; T]$, is commensurate with

$$
\int_{0}^{T} E V A_{t}^{E}=\int_{0}^{T}[q(t) E(t)+M(E(t), t)-C(E(t), t)] e^{-r t} d t
$$

We want to find time, $T$, and the magnitude of environmental degradation, $E(t)$, which maximize Equation (3) subject to the constraint of Equation (1). This problem can be analyzed in the variational framework and yields a tractable result because it is a special case with regards to the functional form and transversality condition [59]. Due to the fact that the terminal point is not fixed, there may be many paths satisfying the Euler equation. To pick up the correct transversality conditions, i.e., the terminal condition that can distinguish the optimal path from those satisfying the Euler equation, we have to figure out the terminal condition [60]. The terminal condition for the problem in Equation (3) is consistent with the following Condition (4) [59-62]:

$$
E\left(t_{1}\right) \geq E_{1}, t_{1} \text { free, } E_{1} \text { fixed }
$$

This implies that environmental degradation lasts as long as there is a budget surplus $\left(E\left(t_{1}\right) \geq E_{1}\right)$ and there is no restriction on the last time period (variable-time problem) with environmental degradation, $t_{1}$. The transversality conditions for the terminal condition are expressed in Equation $(5 \mathrm{a}, \mathrm{b})$ :

$$
\begin{gathered}
\left(F_{E}^{\prime}\right)_{t=t_{1}} \leq 0\left(=0 \text { if } E^{*}\left(t_{1}\right)>E_{1}\right. \\
\left(F-E F_{E}^{\prime}\right)_{t=t_{1}}=0
\end{gathered}
$$

$S(t)$ is the remaining stock of the natural environment at time $t$, whereby

$$
S(t)=E_{0}-\int_{0}^{t} E(t) d t
$$

Thus, $S(t)=-E(t)$ and our problem is as follows:

$$
\left.\begin{array}{c}
\max _{S(t), T} \int_{0}^{T}[-q(t) S(t)+M(S(t), t)-C(-S(t), t)] e^{-r t} d t \\
E(0)=E_{0}, S(T) \geq 0
\end{array}\right\}
$$

The integrand Function (7) does not contain all three arguments of the objective functional, $F(t, S(t), S(t))$. S(t), the remaining stock of the natural environment, is missing from the integrand function $F$. This is one of four special cases in the calculus of variations, which yields a special version of the Euler equation ([61], pp. 37-45). This is a special case of the form $F=F(t, S)$ whereby $F$ does not depend on $S$ but rather on its degradation rate, $S(t)$. This implies that $F_{S}^{\prime}=0$. Hence, the Euler equation, $\frac{\partial F}{\partial S}-\frac{d}{d t}\left(\frac{\partial F}{\partial S}\right)=0$, reduces to $\frac{d F_{S}}{d t}=0 \forall t \in[0, T]$. This implies that the time derivative of $F_{x}^{\prime}(\mathrm{t}, x)$ is $0 \forall t \in[0, T]$. This, after integration, yields the following solution of the Euler first-order differential equation:

$$
\frac{\partial F(t, S)}{\partial S}=\text { constant }
$$


Applied for our problem, the Euler equation corresponds with the following expression, Equation (9):

$$
\left[-q(t)-M_{E}^{\prime}(-S(t), t)+C^{\prime}{ }_{E}(-S(t), t)\right] e^{-r t}=-c
$$

whereby $c$ is an arbitrary constant.

According to the transversality condition corresponding to the terminal requirements $\left(F^{\prime}{ }_{x}\right)_{t=t_{1}} \leq$ $0\left(=0\right.$ if $\left.x^{*}\left(t_{1}\right)>x_{1}\right)$, the left-hand-side of $(9)$ is equal or less than zero $(\leq 0)$ at $t=T$. Hence, $\mathrm{c} \geq 0$, and (9) can be rewritten as:

$$
\begin{aligned}
{\left[-q(t)-M^{\prime}(-S(t), t)+C^{\prime}{ }_{E}(-S(t), t)\right] } & =-c e^{r t} \\
{\left[q(t)+M^{\prime}(-S(t), t)-C^{\prime}{ }_{E}(-S(t), t)\right] } & =c e^{r t}
\end{aligned}
$$

The left-hand side of this equation is the marginal contribution of the environmental degradation to $\operatorname{EVA}\left(\frac{\partial E V A(E(t), t)}{\partial E(t)}\right)$. Thus, (12) tells us that in the optimum the marginal contribution of environmental degradation must increase exponentially with a rate equal to the discount factor $r$ [59].

Assuming that the discount factor $r$ is a measure for the marginal returns of capital employed in the activities related to environmental degradation has repercussions on the intensity of environmental degradation. Greater discount rates correspond with a less advanced stage of economic development. This is in line with the Solow model of economic growth, which predicts decreasing returns on capital employed until marginal utility of one unit of additional investment leads to zero growth of the per capita income [63]. This means that in advanced economies, such as Japan or the European Union, with negligibly low or negative interest rates, we could expect zero or negative growth of profits induced by the environmental degradation. Zero growth of profits related to environmental degradation corresponds with environmental conservation and negative profits induced by environmental degradation correspond with environmental upgrading. By contrast, in less-developed countries, which have scarce capital stock, environmental degradation that leads to capital accumulation subsequently has a greater contribution (shadow value) to the economic value added. Hence, we could expect a greater level of the environmental degradation in the less-developed countries.

Equation $(5 b)$ represents the second transversality condition corresponding to the terminal requirements of our problem as represented in Equation (6), which is:

$$
\left(F-S F_{S}^{\prime}\right)_{t=t_{1}}=0
$$

Applied to Equation (7), the second transversality condition (12) has the following form:

$$
\begin{aligned}
{[-q(T) S(T)+M} & (-S(T), T)-C(-S(T), T)] e^{-r T} \\
& -S(T)\left[-q(T)-M^{\prime}(-S(T), T)+C^{\prime}{ }_{E}(-S(T), T)\right] e^{-r T}=0
\end{aligned}
$$

After some basic transformations, Equation (13) can be reformulated as follows (for a detailed derivation see Appendix A):

$$
\frac{\partial C(-S(T), T)}{\partial E} \frac{E}{C(-S(T), T)}=1+\frac{M(E(t), t)}{C(-S(T), T)}\left(\frac{\partial M(-S(T), T)}{\partial E} \frac{E}{M(-S(T), T)}-1\right)
$$

$\frac{\partial M(-S(T), T)}{\partial E} \frac{E}{M(-S(T), T)}$ on the right-hand side of Equation (14) is the elasticity of the manufacturing sector with respect to the extraction of natural resources and environmental degradation $\varepsilon_{M}$.

$$
\varepsilon_{E}^{C}=\frac{\partial C(-S(T), T)}{\partial E} \frac{E}{C(-S(T), T)}=1+\frac{M(E(t), t)}{C(-S(T), T)}\left(\varepsilon_{M}-1\right)
$$


Without nature's contribution to the MVA, Equation (14) would have the following form:

$$
\varepsilon_{E}^{C}=\frac{\partial C(-S(T), T)}{\partial E} \frac{E}{C(-S(T), T)}=1
$$

This implies that the social optimizer continues exploiting the environment and resources until the juncture at which the elasticity of costs with respect to depletion is unity.

According to Equation (15), in the case with linkages between the manufacturing sector and the exploitation of the environment and resources, extraction stops at a time at which the elasticity of externality related costs with respect to the extraction, $\varepsilon_{E}^{C}$, is $\left[1+\frac{M(E(t), t)}{C(-S(T), T)}\left(\varepsilon_{M}-1\right)\right]$. The value of this term depends on $M V A^{E}$, its ratio to the costs of exploitation, $\frac{M(E(t), t)}{C(-S(T), T)}$ and the value of $\varepsilon_{M}$. As mentioned above, based on the theoretical elaborations and empirical evidence we expect a positive sign for $(\partial M(E(t), t)) /(\partial E(t))>0)$ and consequently for $\varepsilon_{M}\left(=\left(\frac{\partial M(-S(T), T)}{\partial E} \frac{E}{M(-S(T), T)}\right)\right.$ because $\frac{E}{M(-S(T), T)} \geq 0$. Hence, $\left(1-\varepsilon_{M}\right)$ and consequently the whole right-hand side of Equation (15) is positive. The magnitude is mostly dependent on the ratio of $M V A^{E}$ and the costs of exploitation, $\frac{M(E(t), t)}{C(-S(T), T)}$. If the manufacturing sector benefits more from the exploitation of nature, a larger manufacturing sector implies a higher value for $\varepsilon_{E}^{C}$. This means that in optimum in an economy with a great contribution of environmental degradation to the MVA, depletion of environmental amenities stops at a greater threshold.

The left-hand side of the elasticity model in Equation (15) indicates the responsiveness of the environment and mineral endowments-related externalities at the subjective optimum of the social optimizer in a hypothetical country. The equation reveals that a greater ratio of environment and resources' contribution to the MVA to externalities corresponds to a greater threshold for $\varepsilon_{E}^{C}$ if $\left(\varepsilon_{M}-1\right)>0$. This means that as long as a one percent increase in the exploitation of nature leads to more than a one percent increase of the $M V A^{E}$, then the level of the acceptable degradation is greater than 1. If a one percent increase of the exploitation of natural environment leads to less than one percent of environmental degradation then an increase of exploitation of the environment and minerals by one percent leads to less than a one percent increase of the externalities. In accordance with the law of diminishing returns, increasing use of the natural resources leads to a gradually decreasing yield. This means that at the saturation phase of manufacturing a relatively low value of $\varepsilon_{M}$ can be expected. This would reduce the frontiers of the acceptable pollution from the perspective of the social optimizer.

To assure this level of nature use the government would induce environmental regulations and conservation policies. This threshold is much higher in the more natural resource-based and pollution-intensive industries. Knowledge or tertiary sector-reliant economies are less dependent on the exploitation of natural resources and environmental degradation. Hence, the heavy industry that has the greatest carbon footprint faces a greater regulatory burden in the face of the increasing stringency of environmental regulations than the cleaner tertiary sector or knowledge economy. This has been confirmed in the framework of a multisector elasticity model in Sadik-Zada, Loewenstein and Hasanli [64].

This means that the pollution threshold is endogenous to the stage of economic development, and this threshold can be satisfied by employing cleaner production technologies or by outsourcing dirty industries in the countries that experience the industrialization phase. This decision depends on a myriad of factors.

Whether such costs could really trigger the relocation of the heavy industry overseas is nevertheless a question, which can only be answered after the scrutiny of the individual industry cases. Environmental degradation and related costs are just one of many facets that determine the relocation decision of the individual firms [65-69]. Resource and asset seeking, market seeking and efficiency seeking are three major factors that could trigger the multinational enterprises to relocate their production facilities [69]. Lax environmental regulations are often not a sufficient condition 
for relocation. Especially the narrowness of the local markets and lack of a skilled labor force could outweigh the advantages provided by lax environmental regulations.

\section{Methodology}

The literature identifies three problems related to the empirical analysis of issues related to international trade flows, environmental policies and atmospheric pollution. These are aggregation bias, panel heterogeneity and unobserved foreign regulation $[16,70,71]$. To account for these problems, the study employs pooled mean group (PMG) and dynamic fixed effects (DFE) estimators.

Our empirical strategy is in line with Cavalcanti et al. [72] and is based on the following model specification:

$$
\ln P H H_{i t}=a_{j}+\beta_{j 1} \ln \_ \text {Stringency } y_{j t}+\beta_{j 2} \ln \_P o H_{j t}+\beta_{j 3} \mathrm{X}_{j t}+u_{i j}
$$

where $a_{j}$ denotes country-specific fixed effects, $\ln \_$Stringency $y_{j t}$ is the indicator for the stringency of environmental policies and $\ln \_P o H_{j t}$ is a proxy for the technological progress induced by environmental regulations for countries $j=\overline{1, J}$ and time periods $t=\overline{1, T}$. The major focus of this study is, nevertheless, on the bivariate relationship between income inequality and fine wine imports. The advantage of the parsimoniousness of the model is that the broad number of country-specific time-irreversible factors is captured by the country-specific deterministic factor. The same holds for $u_{i j}$ with respect to the unobserved common factors [72].

The unit root tests indicate that the variables of interest are a mixture of stationary at level, $\mathrm{I}(0)$, and first difference, I(1). Hence, the fixed effect, random effect or generalized method of moments (GMM) estimators requiring the stationarity of all time series are not efficient in this case. In addition, the pooling of the individual groups in the fixed effects, random effects and GMM implies the identity of all the slope coefficients across countries. As shown in Pesaran et al. [17], this assumption is mostly statistically inconsistent.

For the mixture of the I(0) and I(1) series, the autoregressive distributed lag ( ARDL) based mean group (MG) or PMG procedure are the feasible methodology. The model crashes if one of the estimation variables is a I(2) process [17]. (P)MG also solves the endogeneity problem by taking into consideration the feedback effects. The endogeneity issue, nevertheless, is not the central issue, in the estimations because it is plausible to assume that wine imports do not influence the level of income inequality or wealth concentration nor the level of income in the respective countries. Due to the mixture of $\mathrm{I}(0)$ and I(1) series, panel heterogeneity and cross-sectional dependence, we employ the panel analysis techniques suggested in Pesaran et al. [17]. The choice between MG and PMG estimators has to be made based on the Hausman test. PMG yields homogenous long-run coefficients, but allows for country-specific intercepts, short-run coefficients (adjustment speed) and error variances [73]. Based on the Hausman test statistics for the case of Dataset 2, we conclude that the PMG estimator, the efficient estimator under the null hypothesis, is preferred. Due to missing values, the implementation of the MG estimation in the case of the Dataset 1 was not feasible. For this reason, the results for Dataset 1 are confined to the presentation of the PMG estimators.

\section{Data}

In contrast to the existing empirical literature on the environmental regulation-trade nexus, the study does not employ gross imports as a measure of strength of the $\mathrm{PHH}$; and per capita GDP, energy efficiency, returns on energy invested of gross greenhouse gas emissions, rule of law or other institutional variables are employed as the measure of environmental regulations [74,75]. As a measure of the PHH intensity we employ the novel methodology for the approximation of the carbon emissions from fossil fuel combustion in imports in megatons of $\mathrm{CO}_{2}\left(\mathrm{MtCO}_{2}\right)$. This methodology has been suggested in Wiebe and Yamano [76]. They combine the OECD Inter-Country Input-Output (ICIO) database with statistics on carbon emissions. The data have been generated on the basis of a computable input-output model translated into carbon terms by multiplying the values by carbon emission factors. 
To quantify the emission multiplier for final demand, carbon intensities are combined with the Leontief inverse of the ICIO. The fuel combustion database of the International Energy Agency (IEA) provided the data on carbon emissions from fossil fuels.

The data are available for 26 OECD countries for the time interval between 1995 and 2011. The countries are the following: Australia, Austria, Belgium, Canada, Czech Republic, Denmark, Finland, France, Germany, Greece, Hungary, Ireland, Italy, Japan, Korea, Netherlands, Norway, Poland, Portugal, Slovak Republic, Spain, Sweden, Switzerland, Turkey, UK, and the US. To assure its compatibility with the $\mathrm{PHH}$, the approximations of the quantity of the carbon emissions embodied in trade are calculated under the equal carbon intensity (ECI) assumption, because taking the emission factors of the developing countries with inferior environmental technologies would substantially overstate the magnitude of the pollution haven effect. Because of its congruence with the $\mathrm{PHH}$, Garsous [75] himself suggests employing carbon emissions embodied in the trade indicator as an instrument for the strength of the PHH. Table 1 below shows the description of the data used in this study.

Table 1. Description of data.

\begin{tabular}{|c|c|c|}
\hline Variable & Description/Transformation & Source \\
\hline $\begin{array}{l}\text { Carbon emissions } \\
\text { embodied in imports }\end{array}$ & $\begin{array}{l}\text { This indicator reports the per capita carbon emissions from fossil fuel } \\
\text { combustion embodied in imports and exports in for } 63 \text { countries and } 34 \\
\text { industries between } 1995 \text { and } 2011 \text {. }\end{array}$ & OECD (2020) \\
\hline Recycling rate & $\begin{array}{l}\text { The share of the recycled municipal waste. This dataset shows data } \\
\text { provided by member countries' authorities through the questionnaire on } \\
\text { the state of the environment (OECD/Eurostat). They were updated or } \\
\text { revised on the basis of data from other national and international sources } \\
\text { available to the OECD Secretariat, and on the basis of comments received } \\
\text { from national delegates (OECD 2020). }\end{array}$ & OECD (2020) \\
\hline $\begin{array}{l}\text { Environmental policy } \\
\text { stringency }\end{array}$ & $\begin{array}{l}\text { The OECD Environmental Policy Stringency Index (EPS) is a } \\
\text { country-specific and internationally comparable measure of the } \\
\text { stringency of environmental policy. Stringency is defined as the degree to } \\
\text { which environmental policies put an explicit or implicit price on polluting } \\
\text { or environmentally harmful behavior. }\end{array}$ & OECD (2020) \\
\hline Trade openness & $\begin{array}{l}\text { Trade is the sum of exports and imports of goods and services measured } \\
\text { as a share of gross domestic product. }\end{array}$ & WB WDI (2020) \\
\hline $\begin{array}{l}\text { Environmentally } \\
\text { adjusted multifactor } \\
\text { productivity } \\
\text { (EAMFP) }\end{array}$ & $\begin{array}{l}\text { EAMFP growth measures the residual growth in the joint production of } \\
\text { both the desirable and the undesirable outputs that cannot be explained } \\
\text { by changes in the consumption of factor inputs (including labor, produced } \\
\text { capital and natural capital). Therefore, for a given growth of input use, } \\
\text { EAMFP increases when GDP increases or when pollution decreases. }\end{array}$ & OECD (2020) \\
\hline Per capita GDP & Average GDP in constant 2010 US Dollars & WB WDI (2020) \\
\hline Openness & $\begin{array}{l}\text { Trade is the sum of exports and imports of goods and services measured } \\
\text { as a share of gross domestic product. }\end{array}$ & WB WDI (2020) \\
\hline
\end{tabular}

\section{Estimation Results}

The PMG estimators compiled in Table 2 reveal that the stringency of environmental regulations have no statistically significant short-term effect on carbon imports. The estimations reveal, nevertheless, a strong and statistically significant robust long-run impact of environmental policy stringency on carbon leakage: in the long run, a one percent increase of the level of the environmental policy stringency leads to a $0.304-0.775$ percent increase of carbon emissions embodied in imports. The short-run effect of environmental policy stringency vanishes if we control for other variables.

To assess the impact of trade liberalization on carbon leakage, the study employed the share of trade volumes (openness), i.e., the sum of the imports and exports, to GDP, as an independent variable. The estimations show that in the long-run, a one percent increase of trade openness leads to a 0.496-1.012 percent increase of carbon emissions embodies in imports (Models 2 and 3). The results with regards to the short-term effects are not unambiguous: the statistical significance of the positive short-term effect in Model 2 vanishes if we control for the level of the per capita income. 
Table 2. Pooled mean group (PMG) estimators.

\begin{tabular}{|c|c|c|c|c|c|c|c|c|c|c|}
\hline \multicolumn{11}{|c|}{ Dependent variable: Per capita carbon emissions embodied in imports } \\
\hline \multirow{2}{*}{ VARIABLES } & \multicolumn{2}{|c|}{ Model 1} & \multicolumn{2}{|c|}{ Model 2} & \multicolumn{2}{|c|}{ Model 3} & \multicolumn{2}{|c|}{ Model 4} & \multicolumn{2}{|c|}{ Model 5} \\
\hline & ec & Short Run & ec & Short Run & ec & Short Run & ec & Short Run & ec & Short Run \\
\hline \multirow[t]{2}{*}{ ec } & & $-0.231 * * *$ & & $-0.177^{* * *}$ & & $-0.193^{* * *}$ & & $-0.203 * * *$ & & $-0.203^{* * *}$ \\
\hline & & $(0.0480)$ & & $(0.0454)$ & & $(0.0636)$ & & $(0.0385)$ & & $(0.0385)$ \\
\hline \multirow[t]{2}{*}{ D.lnStringency } & & $-0.199 * *$ & & -0.0714 & & -0.0404 & & -0.0156 & & -0.0156 \\
\hline & & $(0.0540)$ & & $(0.0589)$ & & $(0.0488)$ & & $(0.0381)$ & & $(0.0381)$ \\
\hline \multirow[t]{2}{*}{ lnStringency } & $0.775^{* * *}$ & & $0.621 * * *$ & & $0.480^{* * *}$ & & $0.304 * *$ & & $0.304^{* *}$ & \\
\hline & $(0.0383)$ & & $(0.0320)$ & & $(0.0357)$ & & $(0.123)$ & & $(0.123)$ & \\
\hline \multirow[t]{2}{*}{ lnOpen } & & & $1.012^{* * *}$ & & $0.496^{* * *}$ & & & & & \\
\hline & & & $(0.115)$ & & $(0.0702)$ & & & & & \\
\hline \multirow[t]{2}{*}{ D.lnOpen } & & & & $0.260^{* *}$ & & 0.108 & & & & \\
\hline & & & & $(0.108)$ & & $(0.0739)$ & & & & \\
\hline \multirow[t]{2}{*}{ ln_PCI } & & & & & $0.981^{* * *}$ & & $3.101 * * *$ & & & \\
\hline & & & & & $(0.145)$ & & $(0.526)$ & & & \\
\hline \multirow[t]{2}{*}{ D.ln_PCI } & & & & & & $2.873^{* * *}$ & & $2.281 * * *$ & & \\
\hline & & & & & & $(0.309)$ & & $(0.251)$ & & \\
\hline \multirow[t]{2}{*}{ Open } & & & & & & & 0.000281 & & 0.000281 & \\
\hline & & & & & & & $(0.000391)$ & & $(0.00039)$ & \\
\hline \multirow[t]{2}{*}{ ln_RECLNG } & & & & & & & $-0.145^{* *}$ & & $-0.145^{* *}$ & \\
\hline & & & & & & & $(0.0678)$ & & $(0.0678)$ & \\
\hline \multirow[t]{2}{*}{ D.Open } & & & & & & & & $3.06 e-05$ & & $3.06 e-05$ \\
\hline & & & & & & & & $(8.15 e-05)$ & & $(8.15 e-05)$ \\
\hline \multirow[t]{2}{*}{ D.ln_RECLNG } & & & & & & & & -0.0274 & & -0.0274 \\
\hline & & & & & & & & $(0.0231)$ & & $(0.0231)$ \\
\hline \multirow[t]{2}{*}{$\ln \mathrm{PCI} 2$} & & & & & & & & & $1.550 * * *$ & \\
\hline & & & & & & & & & $(0.263)$ & \\
\hline \multirow[t]{2}{*}{ D.lnPCI2 } & & & & & & & & & & $1.140^{* * *}$ \\
\hline & & & & & & & & & & $(0.125)$ \\
\hline \multirow[t]{2}{*}{ Constant } & & $1.156^{* * *}$ & & -0.0775 & & $-1.583^{* * *}$ & & $-5.480 * * *$ & & $-5.480^{* * *}$ \\
\hline & & $(0.227)$ & & $(0.0528)$ & & $(0.533)$ & & (1.093) & & (1.093) \\
\hline Observations & 400 & 400 & 384 & 384 & 384 & 384 & . & . & . & . \\
\hline
\end{tabular}

We found that per capita income has a robust statistically significant positive short- and long-run effect on carbon emissions embodied in imports. The long-term elasticity ranges between 0.981 and 3.101 percent. The short-term elasticity ranges between 2.281 and 2.873 percent (Models 3 and 4). We controlled also for the squared value of the natural logarithm of $\mathrm{PCI}, P C I^{2}$, and found a robust positive relationship between this variable and carbon imports. The long-run coefficient of $(P C I)^{2}$ is 1.550 and the short-run coefficient of $(P C I)^{2}$ is 1.140 (Model 5).

To account for the $\mathrm{PoH}$, we employed the recycling rate of the municipal waste as a possible proxy for the development of the carbon-saving technologies and found that their deployment has a statistically significant robust negative impact on carbon imports: in the long term, a one percent increase of the recycling rate leads to a 0.145 percent decrease of carbon emissions embodied in imports. We detected no statistically significant short-term effect of the recycling rate on carbon imports (Models 4 and 5).

Controlling for a more comprehensive proxy for the PoH, the EAMFP, which is, in contrast to the recycling rate, more relevant but less precise, reveals that an increasing EAMPF corresponds with a slight decrease of the long-run carbon imports: a one percent increase of the EAMFP (environmentally adjusted multifactor productivity) leads to a -0.0441 percent decrease of carbon imports (Table A2). To account for the effect of tertiarization, we controlled for the share of the services sector in GDP. The estimations revealed a weak negative long-run effect of tertiarization on carbon imports, whereby the result is not robust (Tables A1 and A2). This could be the consequence of the shortness of the available time series data. Economic structure changed insignificantly between 1995 and 2011. 
To address the tertiarization hypothesis, the employment of a longer time series data would be more conclusive.

\section{Concluding Remarks}

The atmosphere in its function as a sink for GHGs is definitely a global common pool resource. Hence, at least in the context of climate change, a purely national perspective on the environmental Kuznets curve is not satisfactory. The juxtaposition of the two strands of literature-the literature on the EKC on the one side and the pollution haven conjecture on the other side-enabled a substantial broadening of the perspective on the income-environment relationship. The analysis of the income-environment relationship has been extended from a purely national to international perspective.

The relevance of carbon leakage from strictly regulated jurisdictions towards the jurisdictions with lax environmental standards has been emphasized immediately after the proliferation of the EKC hypothesis in the early 1990s by the leading environmental and resource economists [52]. Despite an early impetus to consider the relocation of the pollution-intensive industries overseas, both theoretical and empirical literature ignored the limitations of the purely national perspective. Empirical validation of the inverted U-shaped income-environment relationship for the individual countries and country groups led not only to the empowerment of the EKC to one of most cited stylized facts of the economics discipline, but also to the establishment of the growth optimism with regards to environmental upgrading [77]. The studies to test the pollution haven hypothesis and its antipode, the Porter effect, evolved separately, and not in the context of the environmental Kuznets curve paradigm [16,78].

To address the challenge of merging two concepts-the inward-oriented EKC hypothesis and the pollution haven hypothesis-this study embedded both concepts within the framework of the structuralist paradigm of development economics $[27,28,37,79]$. To this end, the study set out a simple variational model of environmental degradation. Due to its special case with respect to the transversality conditions, the model yields tractable results in the framework of the calculus of variations [59].

The model revealed that, at least on the theoretical level, the ratio of the absolute utility from environmental degradation to the absolute costs related to environmental degradation, and the elasticity of the manufacturing output with respect to environmental degradation are the determinants of the magnitude of environmental degradation. This has two implications. First, the countries whose manufacturing sector enjoys greater linkages from polluting activities have a greater pollution threshold (peak pollution). Second, the countries that carry greater losses induced by environmental degradation tend to get peak pollution at a lower magnitude of environmental degradation. The crux of the matter is, however, the ratio of the utility to externalities related to environmental degradation.

In addition, the elasticity of the manufacturing sector value added to environmental degradation plays an important role in terms of the actual optimal level of environmental degradation. If a one percent increase in the magnitude of environmental degradation leads to less than a one percent increase of the manufacturing value added, then such an economy does not experience environmental degradation but rather environmental upgrading and follows conservation policies. If we think about this in terms of the Solow model of economic growth, then the economies at the relatively mature stages of economic development have low growth multiplier effects that emanate from the depletion of environmental amenities.

The central implication of this theoretical model is not the determination of the numeric value of the threshold of pollution but rather the recognition of the fact that countries at different stages of economic development have different thresholds of environmental degradation. The stringency of environmental policies is endogenous to this threshold, This result is predicated on the sectoral interaction patterns and sectoral structure of the respective economies. This implies that the same pollution activity could be economically and socially inappropriate for the developed settings and desirable in the less developed settings. These differences provide a basis for the emergence of the pollution havens. 
The central argument against the pollution haven hypothesis is related to the small weight of the environmental costs in the share of total costs and the significance of other factors like market and efficiency seeking as determinants of FDI flows. The largest steel companies did not relocate from the advanced countries to the less developed countries. The advantages of the large market size, natural resource base, human capital etc. could countervail the disadvantage of the strict environmental regulations. Under such conditions, deployment of advanced carbon-saving technologies makes more sense than relocating to developing countries. This is the logic behind the Porter hypothesis $[11,13,68,80]$.

The revolution in the time series econometrics in the late 1990s [17], and especially the proliferation of the autoregressive distributed lag models, led to a surge of empirical assessments of the income-environment relationship, and especially the EKC hypothesis for the individual country cases and groups of countries [81]. None of these studies, however, accounted for carbon leakage. The panel estimations, based on the usual fixed or random effects, mostly ignored the time series characteristics of the underlying data, endogeneity issues and heterogeneity of the countries in the dataset. The empirical literature on pollution havens has been employing rather fuzzy instruments to approximate the carbon leakage.

To address all of these issues, the study employed pooled mean group estimators that account both for nonstationarity, endogeneity and panel heterogeneity issues. In addition, the study employs, for the first time, more precise indicators of the environmental policy stringency. pollution haven and Porter effects [72,73].

The pooled mean group estimators provide a strong validation for the pollution haven conjecture. Environmental policy stringency leads to carbon leakage. The limitation of the pollution haven effect by the deployment of the novel carbon-saving technologies is rather weak. Tertiarization, per capita income and trade openness are also drivers of carbon leakage.

The confirmation of the pollution haven hypothesis shows that environmental stringency, which is confined to the boarders of the national state, or even regional integration blocks could lead to sub-optimal solutions in terms of global climate change. Hence, the proposal of the European Commission concerning the EU border carbon tax, if well designed, could contribute to the reduction of the carbon leakage and enhance carbon-saving innovations [82]. This kind of policies has, nevertheless, to be combined with the developmental considerations in developing and especially low-income countries. Because of the decreasing FDI influx owing to the carbon border tax, carbon tariffs could have negative indirect repercussions for the poverty and employment in the developing countries.

Empirical validation of the strong pollution haven and weak Porter effects shows that in reality, the inverted U-shaped income-environment relationship is not an indication for the long-run upgrading of environmental quality or prevention of environmental degradation. Environmental upgrading within advanced economies could be the result of the relocation of dirty industries to the developing areas with lax environmental standards. If so, then the net GHG-emission effect of this kind of relocation is positive. This implies that the national EKC is just an artifact.

Author Contributions: Conceptualization, E.R.S.-Z.; Empirical methodology, E.R.S.-Z. and M.F.; Writing-original draft preparation, E.R.S.-Z. and M.F.; Writing-review and editing, M.F. and E.R.S.Z.; Supervision, E.R.S.-Z. All authors have read and agreed to the published version of the manuscript.

Funding: This research received no external funding.

Acknowledgments: We would like to express our deep gratitude to Wilhelm Loewenstein for his guidance, enthusiastic encouragement and useful critiques of this research work. I would also like to thank Kamiar Mohaddes from the University of Cambridge for his advice on the employment of the pooled mean group approach. We are also grateful to the managing editors and three anonymous reviewers for their helpful comments and suggestions.

Conflicts of Interest: The authors declare no conflict of interests. 


\section{Appendix A. Derivation of Equation (14)}

$$
\begin{gathered}
M(-S(T), T)-C(-S(T), T)-\frac{\partial M(-S(T), T)}{\partial E} \cdot E+\frac{\partial C(-S(T), T)}{\partial E} \cdot E=0 \\
\frac{\partial C(-S(T), T)}{\partial E} \cdot E=\frac{\partial M(-S(T), T)}{\partial E} \cdot E+C(-S(T), T)-M(-S(T), T) \quad \mid \div C \\
\frac{\partial C(-S(T), T)}{\partial E} \frac{E}{C(-S(T), T)}=1-\frac{M(-S(T), T)}{C(-S(T), T)}+\frac{\partial M(-S(T), T)}{\partial E} \frac{E}{C(-S(T), T)} \\
\frac{\partial C(-S(T), T)}{\partial E} \frac{E}{C(-S(T), T)}=1-\underbrace{\frac{M(-S(T), T)}{C(-S(T), T)}}_{\Leftrightarrow}+\frac{\partial M(-S(T), T)}{\partial E} \frac{E}{M(-S(T), T)} \underbrace{\frac{M(-S(T), T)}{C(-S(T), T)}} \\
\frac{\partial C(-S(T), T)}{\partial E} \frac{E}{C((18)-S(T), T)}=1+\frac{M(E(t), t)}{C(-S(T), T)}\left(\frac{\partial M(-S(T), T)}{\partial E} \frac{E}{M(-S(T), T)}-1\right)
\end{gathered}
$$

\begin{tabular}{|c|c|c|}
\hline & (1) & (2) \\
\hline VARIABLES & ec & SR \\
\hline ec & & $\begin{array}{c}-0.347^{* * *} \\
(0.0576)\end{array}$ \\
\hline D.lnStringency & & $\begin{array}{c}0.0491 \text { ** } \\
(0.0208)\end{array}$ \\
\hline L3D.InSERV & & $\begin{array}{c}-0.0256 \text { ** } \\
(0.0116)\end{array}$ \\
\hline D.lnEAMPF & & $\begin{array}{c}0.0112 * \\
(0.00590)\end{array}$ \\
\hline D.ln_PCI & & $\begin{array}{l}0.698 \text { * } \\
(0.383)\end{array}$ \\
\hline L2D.InPCI2 & & $\begin{array}{l}0.185^{* * *} \\
(0.0657)\end{array}$ \\
\hline lnStringency & $\begin{array}{c}-0.164 * * * \\
(0.0589)\end{array}$ & \\
\hline L3.lnSERV & $\begin{array}{c}0.0331 \\
(0.0287)\end{array}$ & \\
\hline $\operatorname{lnEAMPF}$ & $\begin{array}{c}-0.0441^{*} \\
(0.0244)\end{array}$ & \\
\hline ln_PCI & $\begin{array}{l}-0.273 \\
(0.676)\end{array}$ & \\
\hline L2.lnPCI2 & $\begin{array}{c}0.345 \\
(0.351)\end{array}$ & \\
\hline Constant & & $\begin{array}{l}-0.773 \\
(0.701)\end{array}$ \\
\hline
\end{tabular}

Table A1. Multivariate pooled mean group estimator.

Observations

Standard errors in parentheses. ${ }^{* * *} p<0.01,{ }^{* *} p<0.05,{ }^{*} p<0.1$. 
Table A2. Multivariate pooled mean group estimator.

\begin{tabular}{|c|c|c|}
\hline \multicolumn{3}{|c|}{ Dependent Variable: Carbon Emissions Embodies in Imports } \\
\hline VARIABLES & ec & SR \\
\hline ec & & $\begin{array}{c}-0.402 * * * \\
(0.0518)\end{array}$ \\
\hline D.lnStringency & & $\begin{array}{c}0.0459 * * \\
(0.0204)\end{array}$ \\
\hline LD.SERVICES & & $\begin{array}{c}0.000265 \\
(0.000189)\end{array}$ \\
\hline D.lnEAMPF & & $\begin{array}{c}0.00815 \\
(0.00506)\end{array}$ \\
\hline D.ln_PCI & & $\begin{array}{c}0.888^{* * *} \\
(0.226)\end{array}$ \\
\hline D.ln_RECYCLING & & $\begin{array}{c}-0.00308 \\
(0.0116)\end{array}$ \\
\hline lnStringency & $\begin{array}{c}-0.125^{* * *} \\
(0.0450)\end{array}$ & \\
\hline L.SERVICES & $\begin{array}{c}-0.000525 * \\
(0.000302)\end{array}$ & \\
\hline $\operatorname{lnEAMPF}$ & $\begin{array}{c}-0.0465^{* *} \\
(0.0193)\end{array}$ & \\
\hline ln_PCI & $\begin{array}{c}0.442^{* * *} \\
(0.153)\end{array}$ & \\
\hline ln_RECYCLING & $\begin{array}{c}-0.00503 \\
(0.0186)\end{array}$ & \\
\hline Constant & & $\begin{array}{c}0.912 \\
(0.617)\end{array}$ \\
\hline
\end{tabular}

Standard errors in parentheses. ${ }^{* * *} p<0.01,{ }^{* *} p<0.05,{ }^{*} p<0.1$.

\section{References}

1. Lee, T.M.; Markowitz, E.M.; Howe, P.D.; Ko, C.-Y.; Leiserowitz, A.A. Predictors of public climate change awareness and risk perception around the world. Nat. Clim. Chang. 2015, 5, 1014-1020. [CrossRef]

2. Baristow, J. Majority of Europeans want stricter measures on air quality. Energy Live News, 4 December 2019.

3. Mavrokefalidis, D. EU poll shows $72 \%$ of EU citizens would back a carbon tax on air travel. Connectin Energy, 14 March 2020.

4. Coren, M.J. Americans: We need a carbon tax, but keep the change. Quartz, 22 January 2019.

5. Faure, M.G.; Partain, R.A. The Role of Environmental Law in Developing Countries; Cambridge University Press (CUP): Cambridge, UK, 2019; pp. 292-314.

6. Conrad, E.; Cassar, L.F. The Environmental Performance Index. In Routledge Handbook of Sustainability Indicators; Routledge: Abingdon, UK, 2018; pp. 294-307. [CrossRef]

7. World Bank Carbon Pricing Dashboard. Available online: carbonpricingdashboard.worldbank.org (accessed on 31 January 2020).

8. Copeland, B.R.; Taylor, M.S. Trade, Growth, and the Environment. J. Econ. Lit. 2004, 42, 7-71. [CrossRef]

9. Rosenthal, E. Lead from old U.S. Batteries sent to Mexico raises risks. New York Times, 8 December 2011.

10. Porter, M.E.; Van Der Linde, C. Toward a New Conception of the Environment-Competitiveness Relationship. J. Econ. Perspect. 1995, 9, 97-118. [CrossRef]

11. D'Adamo, I.; Gastaldi, M.; Rosa, P. Recycling of end-of-life vehicles: Assessing trends and performances in Europe. Technol. Forecast. Soc. Chang. 2020, 152, 119887. [CrossRef]

12. D'Adamo, I.; Falcone, P.M.; Ferella, F. A socio-economic analysis of biomethane in the transport sector: The case of Italy. Waste Manag. 2019, 95, 102-115.

13. Frohwein, T.; Hansjürgens, B. Chemicals Regulation and the Porter Hypothesis: A Critical Review of the New European Chemicals Regulation. J. Bus. Chem. 2005, 2. Available online: https://papers.ssrn.com/sol3/ papers.cfm?abstract_id $=757645$ (accessed on 23 July 2005). 
14. Lindahl, S. Environmental Regulations and Pollution Havens. An Empirical Study of the Most Polluting Industries. Master's Thesis, Goteborgs University, Gothenburg, Sweden, 2016.

15. McWilliams, B.; Zachmann, G. A European Carbon Border Tax-Much Pain, Little Gain. Policy Contrib. 2020. Available online: https://www.bruegel.org/wp-content/uploads/2020/03/PC-05-2020-050320v2.pdf (accessed on 15 March 2020).

16. Jobert, T.; Karanfil, F.; Tykhonenko, A. Degree Of Stringency Matters: Revisiting The Pollution Haven Hypothesis Based On Heterogeneous Panels And Aggregate Data. Macroecon. Dyn. 2018, 23, 2675-2697. [CrossRef]

17. Pesaran, M.H.; Shin, Y.; Smith, R.P. Pooled Mean Group Estimation of Dynamic Heterogeneous Panels. J. Am. Stat. Assoc. 1999, 94, 621-634. [CrossRef]

18. Ayres, R.; Ayres, L. A Handbook of Industrial Ecology. In A Handbook of Industrial Ecology; Edward Elgar Publishing: Cheltenham, UK, 2002.

19. Meadows, D.H.; Meadows, D.L.; Randers, J.; Behrens, W.W. The limits to growth. In Green Planet Blues: Critical Perspectives on Global Environmental Politics; Taylor \& Francis: Abingdon-on-Thames, Oxfordshire, UK, 1972; ISBN 9780429962295.

20. Baumol, W.J. Environmental Protection, International Spillovers and Trade; Almqvist and Wiksell: Stockholm, Sweden, 1971.

21. Markusen, J.R. International externalities and optimal tax structures. J. Int. Econ. 1975, 5, 15-29. [CrossRef]

22. Siebert, H. Environmental quality and the gains from trade. Kyklos 1977, 30, 657-673. [CrossRef]

23. Malenbaum, W. Material Requirements in the United States and abroad in the Year 2000; US National Commission on Materials Policy; University of Pennsylvania: Philadelphia, PA, USA, 1973.

24. Malenbaum, W. World Demand for Raw Materials in 1985 and 2000; McGraw-Hill: New York, NY, USA, 1978.

25. Wårell, L. Trends and developments in long-term steel demand-The intensity-of-use hypothesis revisited. Resour. Policy 2014, 39, 134-143. [CrossRef]

26. Auty, R. Materials intensity of GDP. Resour. Policy 1985, 11, 275-283. [CrossRef]

27. Fisher, A.G.B. Production, Primary, Secondary and Tertiary. Econ. Rec. 1939, 15, 24-38. [CrossRef]

28. Rosenstein-Rodan, P.N. Problems of Industrialisation of Eastern and South-Eastern Europe. Econ. J. 1943, 53, 202. [CrossRef]

29. Marc, M.S.; Fourastié, J. Le grand espoir du XXe siècle. Sociétés 1997, 57, 81-90. [CrossRef]

30. Ragnar, N. Problems of Capital Formation in Underdeveloped Countries (1953). In Trade and Development; United Nations Conference on Trade and Development: Geneva, Switzerland, 2012.

31. Hirschman, A. The Strategy of Economic Development; Yale University Press: New Haven, CT, USA, 1958.

32. Huntington, S.P. Political Development and Political Decay. World Polit. 1965, 17, 386-430. [CrossRef]

33. Eisenstadt, S. Modernization: Protest and change (Modernization of Traditional Society); Prentice Hall: Upper Saddle River, NJ, USA, 1967.

34. Myint, R.B.H. Asian Drama: An Inquiry into the Poverty of Nations. Swed. J. Econ. 1968, 70, 242. [CrossRef]

35. Bruyn, S.M. The environmental Kuznets curve hypothesis. In Economy and Ecology: Towards Sustainable Development; Kluwer Academic Publishers: Dordrecht, The Netherlands, 2000; Volume 18, pp. 77-98.

36. Lewis, W.A. Economic Development with Unlimited Supplies of Labour. Manch. Sch. 1954, 22, $139-191$. [CrossRef]

37. Loewenstein, W.; Bender, D. Labour Market Failure, Capital Accumulation, Growth and Poverty Dynamics in Partially Formalised Economies: Why Developing Countriess Growth Patterns are Different. SSRN Electron. J. 2017. [CrossRef]

38. Engel, E. Die Productions-und Consumtionsverhältnisse des Königreichs Sachsen. Zeitschrift Statistischen Bureaus Königlich Sächsischen Ministeriums Innern 1857, 8, 1-54.

39. Pasinetti, L. Structural Change and Economic Growth; Cambridge University Press: Cambridge, UK, 1981.

40. Pasinetti, L. Structural Economic Dynamics; Cambridge University Press (CUP): Cambridge, UK, 1993.

41. Radetzki, M.; Tilton, J. Conceptual and methodological issues. In World Metal Demand; Resources for the Future: Washington, DC, USA, 1990.

42. Grossman, G.; Krueger, A. Environmental Impacts of a North American Free Trade Agreement. In Environmental Impacts of a North American Free Trade Agreement; National Bureau of Economic Research: Cambridge, MA, USA, 1991. [CrossRef] 
43. Grossman, G.M.; Krueger, A.B. Economic Growth and the Environment. Q. J. Econ. 1995, 110, $353-377$. [CrossRef]

44. Kuznets, S. Economic growth and income inequality. Am. Econ. Rev. 1955, 45, 1-28.

45. Panayotou, T. Demystifying the environmental Kuznets curve: Turning a black box into a policy tool. Environ. Dev. Econ. 1997, 2, 465-484. [CrossRef]

46. Singh, A. UK Industry and the World Economy: A Case of de-Industrialization? In Welfare Aspects of Industrial Markets; Springer Science and Business Media LLC: Berlin, Germany, 1977; pp. 183-214.

47. Black, G.; Kaldor, N. Further Essays on Economic Theory. South. Econ. J. 1980, 47, 245. [CrossRef]

48. Tregenna, F. Characterising deindustrialisation: An analysis of changes in manufacturing employment and output internationally. Camb. J. Econ. 2008, 33, 433-466. [CrossRef]

49. Dinda, S. Environmental Kuznets Curve Hypothesis: A Survey. Ecol. Econ. 2004, 49, 431-455. [CrossRef]

50. Kaika, D.; Zervas, E. The Environmental Kuznets Curve (EKC) theory-Part A: Concept, causes and the CO2 emissions case. Energy Policy 2013, 62, 1392-1402. [CrossRef]

51. Congregado, E.; Feria-Gallardo, J.; Golpe, A.A.; Iglesias, J. The environmental Kuznets curve and CO2 emissions in the USA. Environ. Sci. Pollut. Res. 2016, 23, 18407-18420. [CrossRef]

52. Arrow, K.; Bolin, B.; Costanza, R.; Dasgupta, P.; Folke, C.; Holling, C.; Jansson, B.-O.; Levin, S.; Maler, K.-G.; Perrings, C.; et al. Economic growth, carrying capacity, and the environment. Environ. Dev. Econ. 1996, 1, 104-110. [CrossRef]

53. Littleton, M. The TRIPS Agreement and transfer of climate-change-related technologies to developing countries. Nat. Resour. Forum 2009, 33, 233-244. [CrossRef]

54. Blyde, S.; Acea, C. How Does Intellectual Property Affect Foreign Direct Investment in Latin America? Integr. Trade J. 2003, 7, 135-152.

55. Smith, P.J. How do foreign patent rights affect U.S. exports, affiliate sales, and licenses? J. Int. Econ. 2001, 55, 411-439. [CrossRef]

56. Maskus, K.E.; Reichman, J.H. The globalization of private knowledge goods and the privatization of global public goods. J. Int. Econ. Law 2004, 7, 279-320. [CrossRef]

57. Johnson, D.L.; Ambrose, S.H.; Bassett, T.J.; Bowen, M.L.; Crummey, D.E.; Isaacson, J.S.; Lamb, P.; Saul, M.; Winter-Nelson, A.E.; Johnson, D.N. Meanings of Environmental Terms. J. Environ. Qual. 1997, 26, 581-589. [CrossRef]

58. Agrawal, A.; Gopal, K. Biomonitoring of Water and Waste Water; Springer: Berlin/Heidelberg, Germany, 2013.

59. Becker, R.A.; Sierstad, A.; Sydsæter, K.; Sydsaeter, K. Optimal Control Theory with Economic Applications. Scand. J. Econ. 1989, 91, 175. [CrossRef]

60. Kamihigashi, T. Transversality conditions and dynamic economic behaviour. In The New Palgrave Dictionary of Economics; Research Institute for Economics \& Business Administration, Kobe University: Kobe, Hyogo, Japan, 2008.

61. Chiang, A.C. Elements of Dynamic Optimization; Waveland Pr Inc.: Long Grove, IL, USA, 1992; ISBN 157766096X.

62. Derakhshan-Nou, M. Mathematical Economics and Control Theory: Studies in Policy Optimization; Department of Economics, University of London: London, UK, 1996.

63. Solow, R.M. A Contribution to the Theory of Economic Growth. Q. J. Econ. 1956, 70, 65. [CrossRef]

64. Sadik-Zada, E.R.; Loewenstein, W.; Hasanli, Y. Commodity Revenues, Agricultural Sector and the Magnitude of Deindustrialization: A Novel Multisector Perspective. Economies 2019, 7, 113. [CrossRef]

65. Yee-Cheong, J.L. Innovation: Applying Knowledge in Development; UN Millenium Project; Earthscan: London, UK, 2005.

66. Matsushita, M.; Schoenbaum, T.J.; Mavroidis, P. The World Trade Organization: Law, Practice, and Policy; Oxford International Law Library: Oxford, UK, 2016.

67. Fischer, C.; Greaker, M.; Rosendahl, K.E. Robust technology policy against emission leakage: The case of upstream subsidies. J. Environ. Econ. Manag. 2017, 84, 44-61. [CrossRef]

68. Greaker, M. Spillovers in the development of new pollution abatement technology: A new look at the Porter-hypothesis. J. Environ. Econ. Manag. 2006, 52, 411-420. [CrossRef]

69. Boehringer, C.; Balistreri, E.J.; Rutherford, T.F. The role of border carbon adjustment in unilateral climate policy: Overview of an Energy Modeling Forum study (EMF 29). Energy Econ. 2012, 34, S97-S110. [CrossRef]

70. Levinson, A.; Taylor, M.S. Unmasking the pollution haven effect. Int. Econ. Rev. 2008, 49, 223-254. [CrossRef] 
71. Grether, J.-M.; De Melo, J. Globalization and Dirty Industries: Do Pollution Havens Matter? NBER Working Paper Series; NBER: Cambridge, MA, USA, 2003.

72. Cavalcanti, T.V.D.V.; Mohaddes, K.; Raissi, M. Growth, development and natural resources: New evidence using a heterogeneous panel analysis. Q. Rev. Econ. Finance 2011, 51, 305-318. [CrossRef]

73. Mohaddes, K.; Raissi, M. Do sovereign wealth funds dampen the negative effects of commodity price volatility? J. Commod. Mark. 2017, 8, 18-27. [CrossRef]

74. Millimet, D.L.; Roy, J. Empirical Tests of the Pollution Haven Hypothesis When Environmental Regulation is Endogenous. J. Appl. Econ. 2015, 31, 652-677. [CrossRef]

75. Garsous, G. Trends in Policy Indicators on Trade and Environment; OECD Trade and Environment Working Papers; 2019; Available online: https://www.oecd-ilibrary.org/trade/trends-in-policy-indicators-on-tradeand-environment_b8d2bcac-en (accessed on 1 March 2019). [CrossRef]

76. Wiebe, K.S.; Yamano, N. Estimating CO2 Emissions Embodied in Final Demand and Trade Using the OECD ICIO 2015: Methodology and Results; OECD Science, Technology and Industry Working Papers No. 2016/05; 2016; Available online: https://www.oecd-ilibrary.org/science-and-technology/estimating-co2emissions-embodied-in-final-demand-and-trade-using-the-oecd-icio-2015_5jlrcm216xkl-en (accessed on 3 September 2016).

77. Mikayilov, J.I.; Galeotti, M.; Hasanov, F.J. The impact of economic growth on CO2 emissions in Azerbaijan. J. Clean. Prod. 2018, 197, 1558-1572. [CrossRef]

78. D'Agostino, L.M. How MNEs respond to environmental regulation: Integrating the Porter hypothesis and the pollution haven hypothesis. Econ. Polit. 2015, 32, 245-269. [CrossRef]

79. Fischer, C. Emissions pricing, spillovers, and public investment in environmentally friendly technologies. Energy Econ. 2008, 30, 487-502. [CrossRef]

80. Rutqvist, J. Porter or Pollution Haven? An Analysis of the Dynamics of Competitiveness and Environmental Regulation. Master's Thesis, Uppsala University, Uppsala, Sweden, 2009.

81. Ozturk, I.; Al-Mulali, U. Investigating the validity of the environmental Kuznets curve hypothesis in Cambodia. Ecol. Indic. 2015, 57, 324-330. [CrossRef]

82. Karl, H.; Ranne, O. European environmental policy between decentralization and uniformity. Intereconomics 1997, 32, 159-169. [CrossRef]

(C) 2020 by the authors. Licensee MDPI, Basel, Switzerland. This article is an open access article distributed under the terms and conditions of the Creative Commons Attribution (CC BY) license (http://creativecommons.org/licenses/by/4.0/). 